\title{
Identification of Bioactive Phytoconstituents from the Plant Euphorbia hirta as Potential Inhibitor of SARS- CoV-2: an In-Silico Approach
}

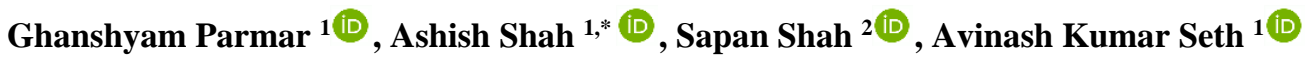 \\ 1 Drug Discovery Lab, Department of Pharmacy, Sumandeep Vidyapeeth, Vadodara, Gujarat, India \\ 2 Department of Pharmaceutical Chemistry, Priyadarshini J L College of Pharmacy, Nagpur, Maharashtra, India \\ * Correspondence: shah_ashishpharmacy@yahoo.co.in (S.S.);
}

Scopus Author ID 57214919105

Received: 10.05.2021; Revised: 4.06.2021; Accepted: 6.06.2021; Published: 9.06.2021

\begin{abstract}
Currently, the entire globe is under the deadliest pandemic of Covid-19 caused by Severe Acute Respiratory Syndrome Coronavirus 2 (SARS-CoV-2). At present, no specific treatment is available to combat COVID-19 infection. Euphorbia hirta (Euphorbiaceae) have been reported for a variety of biological activities, including antiviral. The present investigation aimed to identify potential phytoconstituents of the plant $E$. hirta from the category flavonoids and coumarins against the SARSCoV-2 using in silico approach. The molecular docking studies were performed using two different targets of SARS-CoV-2, namely Main protease ( $\mathrm{M}^{\text {pro}}$; PDB ID: 6M2N) and RNA-dependent RNA polymerase (RdRp; PDB ID: 7BW4). Based on the molecular docking study in comparison with standard drug, four compounds, namely Euphrobianin, Quercetin, 3-o-alpha-rhamnoside, Isoquercitrin, and rutin, were screened against the target $\mathrm{M}^{\text {pro }}$. Three phytoconstituents, euphorbianin, myricetin, and rutin, were screened against the target RdRp. In the in silico toxicity studies of screened phytoconstituents, except myrectin all were predicted safe. Results of euphorbianin and rutin were found more interesting as both compounds had high binding affinity against both targets. Finally, we want to conclude that euphrobianin, quercetin 3-o-alpha-rhamnoside, isoquercitrin, and rutin could be further explored rapidly as they may have the potential to fight against COVID-19.
\end{abstract}

Keywords: in silico study; Euphorbia hirta; flavonoids; coumarins; $\mathrm{M}^{\mathrm{pro}}$; RdRp.

(C) 2021 by the authors. This article is an open-access article distributed under the terms and conditions of the Creative Commons Attribution (CC BY) license (https://creativecommons.org/licenses/by/4.0/).

\section{Introduction}

At the beginning of 2020, the emergence of a global public health emergency was noted due to novel coronavirus disease 2019 (COVID-19). Later, it was determined that Severe Acute Respiratory Syndrome Coronavirus 2 (SARS-CoV-2) is the primary cause of COVID-19 [1,2]. As of 10th May 2021, the virus has caused 3288455 deaths and 157973438 confirmed cases globally [3]. SARS-CoV-2 is a single-stranded RNA virus that belongs to the genus Beta coronavirus. This group also contains SARS-CoV and MERS-CoV, responsible for triggering the pneumonia epidemic in 2003 and 2012, respectively [4,5]. COVID-19 infection can lead to numerous respiratory, hepatic, enteric, and neurological conditions. 2 The SARS-CoV-2 is primarily transmitted through respiratory droplets, aerosol particles, and personal contact [6]. It can enter into respiratory cells by coupling its spike protein to the angiotensin-converting enzyme 2 (ACE-2) receptors present over the pneumocytes in the lungs, which then induces 
the activation of inflammatory and immune reactions. Physiological response to these reactions causes tachypnea, increased cough production, and a rise in body temperature [7].

At present, no specific treatment is available to combat COVID-19 infection. Existing treatment protocols mainly involve using certain repurposed medications, such as Chloroquine/ Hydroxychloroquine, Lopinavir/ Ritonavir, Azithromycin, and Umifenovir. Additionally, certain drugs like, Remdesivir, Favipiravir, and Tocilizumab are currently in the clinical trial phase and are thought to cure COVID-19 [5,8,9]. Besides these synthetic drug products, several vaccines are also in the clinical trial phase, and it will probably take a year or more for these therapies to be launched in the market for community people. Meanwhile, an alternative to testing existing antiviral natural/ herbal products could be explored to find a cure for the current pandemic. Also, according to a World Health Organization (WHO) report, 80\% of people in developing countries rely on herbal remedies for their health management [10].

The family Euphorbiaceae is unique in that it contains highly reputed plants useful in various diseases. This genus has diverse chemical entities with a lot of structural variation sources. Such plants like Amla (Embelica officinalis), Bhoiamli (Phyllanthus fractus), Arendmul (Racinus communis), Dudhi (Euphorbia hirta) and Ratidudhi (Euphorbia thymifolia), etc., are medicinally valuable in the treatment of some chronic disease such as diabetes, hemorrhoid asthma inflammation, etc. [11]. Complementary and alternative medicine (CAM) covers a heterogeneous spectrum of ancient to new-age approaches that intend to prevent or treat disease. A traditional Indian system of medicine has represented a few medications from the traditional indigenous plants in the treatment of liver disease [12]. The Euphorbia hirta L (Euphorbiaceae), commonly known as dudheli in the vernacular language (Gujarati), commonly grows widely in most parts of India and other tropical countries, especially on roadsides and on wasteland $[13,14]$. The E. hirta (EUH) is amply found as a weed plant in roadside and open grasslands. It is erect, slender plant or sometimes found diffused through the soil, leaves are opposite, elliptical, or lanceolate, with a toothed margin. The flowers are cymes, smaller in size [15]. The milky white juice is exhausted upon cutting of stem [16,17]. Traditionally E. hirta is used in respiratory diseases like asthma, bronchitis, and hay fever, due to its analgesic and anti-inflammatory activity [10, 18].

Flavonoids are termed polyphenolic compounds present in the plant parts, which own different biological activities [19]. Based on the literature survey, many flavonoids have been seen as effective against infectious viral diseases by restricting the growth of these deadly viruses at a molecular level [20]. The mechanism behind these antiviral properties of flavonoids is inhibiting molecular receptors and enzymes and interfering with viral replication and translation process [21]. COVID-19 main protease (Mpro) and RNA-dependent RNA polymerase $(\mathrm{RdRp})$ play a vital role in viral replication, translation, and transcription processes in Covid-19. Replication of SARS-CoV-2 could be blocked by targeting the main protease and RdRp. However, other targets are important for the life-cycle of various, but due to vital role in viral replication, translation and transcription process both targets are front line choice for the researchers $[22,23]$. In this study, we performed in silico analysis of phytoconstituents from the category flavonoids and coumarins, obtained from the plant E. hirta to find potential candidates against the SARS-CoV-2. The phytoconstituents are screened based on molecular docking, drug-likeness, and in silico toxicity evaluation. 


\section{Materials and Methods}

\subsection{Preparation of ligand library.}

Twenty-seven different phytoconstituents of E. hirta from the class flavonoid and coumarins reported in various literature were used to prepare the ligand library [24]. All structures were downloaded in the SDF format from the PubChem database. The LigPrep module was used for the preparation of the library. The geometry of all structures was optimized using the OPLS3 force field, and their specific chirality was retained; the generation of tautomer was restricted to 32 .

\subsection{Drug-likeness screening and in silico toxicity prediction of phytoconstituents.}

All the phytoconstituents were screened for their drug-likeness properties. The druglikeness properties were evaluated using the Lipinski rule of five. Additionally, other parameters like no rotatable bond, GI absorption, and $\operatorname{LogS}$ were also predicted. The evaluation of drug-likeliness properties was done using the Schrodinger QuikProp module, where the LigPrep file was used as input. The In silico toxicity prediction of the finally screened compound (based on docking and drug-likeness) was done using VEGA-QSAR. The various toxicological properties like mutagenicity, carcinogenicity, skin sensitization etc., were predicted

\subsection{Protein preparation and receptor grid generation.}

Our study selected two proteins of SARS-CoV-2, namely main protease $\left(\mathrm{M}^{\text {pro }}\right)$ and RNA-dependent RNA polymerase (RdRp). Both proteins are essential for the viral life cycle. Inhibition of these proteins may lead to blockage of further viral life cycle and viral growth. The crystal structures of both protein $\mathrm{M}^{\text {pro }}$ and $\mathrm{RdRp}$ were downloaded from the protein data bank in PDB format. Protein pre-preparation includes assigning bond orders, the addition of formal charges, the addition of hydrogen atoms, and missing chain residues added. The water molecules beyond $5 \mathrm{~A}^{\circ}$ distance from the hetero atom were removed, and a possible ionization state was generated. Finally, after pre-preparation, proteins were energy minimized. The receptor grid was generated after energy minimization. For $\mathrm{M}^{\text {pro }}$ and $\mathrm{RdRp}$, the grid dimensions of protein were grid box dimension around the centroid of ligand was $10 \mathrm{~A}^{\circ} \times 10 \mathrm{~A}^{\mathrm{o}} \times 10 \mathrm{~A}^{\mathrm{o}}$.

\subsection{Molecular docking studies.}

To find ligand-protein interaction and binding affinity, we performed molecular docking studies using the glide module of Schrodinger. The glide docking of selected phytoconstituents was carried using both the protein receptor grid and LigPrep file. The docking calculations were performed in extra precisions (XP) mode. Docking scores of all compounds and ligand-receptor interactions were collected upon completion of docking protocol. The docking methodology was validated by removing co-crystallized ligand and redocked into the active site.

\section{Results and Discussion}

There is an urgent need for therapeutics for controlling coronavirus infections [25]. Replication of SARS-CoV-2 could be blocked by targeting the main protease $\left(3 \mathrm{CL}^{\text {pro }}\right.$ or 
$\mathrm{M}^{\mathrm{pro}}$ )[26] and crucial replicase RNA-dependent RNA polymerase (RdRp) [27]. Traditional therapeutics have shown valuable effects from usage in patients infected with novel SARSCoV-2 [28]. Euphorbia hirta extracts were shown significant antiretroviral activities on the MT4 human T lymphocyte cell line [29]. Therefore, the present study aimed to screen active chemical constituents of Euphorbia hirta to highly conserved proteins, $\mathrm{M}^{\text {pro }}$ and RdRp of SARS-CoV-2, therefore we performed molecular docking studies of all phytoconstituents of E. hirta followed by the study of interacting amino acid residues. Selected phytoconstituents showing best fit are further evaluated for pharmacokinetics and toxicity results to propose them as potential drug candidates.

All the prepared ligands (Figure 1) were docked (XP module) on the prepared proteins (Main protease, PDB ID: 6m2n) and (RdRp, PDB ID: 7BW4) successfully, and the XP docking score was analyzed. The XP docking score for all the ligands is listed in Table 1 and Table 2 and their interactions with amino acid residues. Visual examination of the computationally docked optimal binding poses of chemical constituents of $E$. hirta on $6 \mathrm{~m} 2 \mathrm{n}$ and 7BW4 revealed the significant involvement of various types of interactions viz. hydrogen bonding and hydrophobic interactions, including $(\pi-\pi$ stacking, $\pi-$ cation, and $\pi-\sigma)$ and charged interactions in the stability of the binding of the phytoconstituents to the main protease and RdRp.

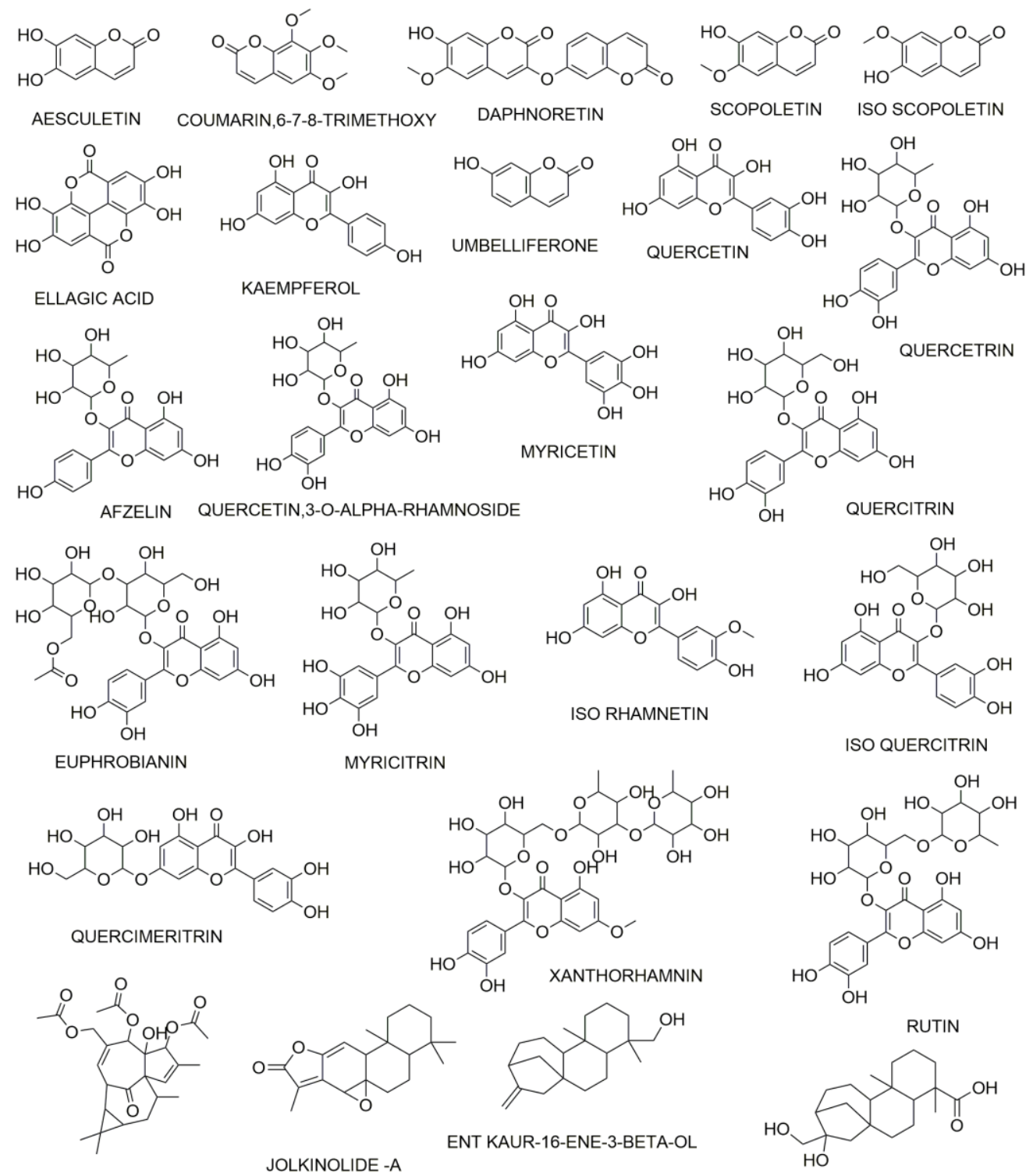

INGENOL TRIACETATE

KAURANE,16-ALPHA, 17,19-TRIHYDROXY:ENT

Figure 1. Two-dimensional structures of phytoconstituents from E. hirta. 
3.1. Molecular docking of selected phytoconstituents with main protease $(6 m 2 n)$.

All the 26 chemical compounds were docked to the active site of $6 \mathrm{~m} 2 \mathrm{n}$. The docking score of all selected phytoconstituents was compared with standard drug lopinavir. As compared to the standard four compounds (Table 1, Figure 2) euphrobianin, Quercetin,3-oalpha-rhamnoside, Isoquercitrin and rutin had a higher binding affinity.

It was observed that euphrobianin had shown the highest binding energy value of -8.4 $\mathrm{kcal} / \mathrm{mol}$ forming various $\mathrm{H}$-bonded and nonbonded interaction contact. The ligand is properly positioned into the binding pocket constructed by polar LEU 141D, ASN 142D, GLY143D, SER144D, GLU166D, ARG188D with hydrophobic MET 165D ( $\pi$-alkyl), CYS 145D ( $\pi$ sulfur), HIS 41D ( $\pi-\pi$ T-shape) and GLN189D amino acids. Similarly, compound quercetin,3o-alpha-rhamnoside interacted with 13 amino acids in the active site with 3 hydrogen bonds THR 26D, GLY 143D, GLU 166D and hydrophobic interactions with THR 25D, HIS 41D, MET 49D, TYR 54D, ASN 142D, CYS 145D, HIS 164D, MET 165D, ASP 187D, ARG 188D amino acid residues. Hydrogen bonding is more enhanced by the interaction of $\mathrm{O} 6$ and $\mathrm{O} 9$ atoms of the ligand with N-atom of THR 26D (distance of $3.25 \mathrm{~A}$ ) and GLU 166D (distance of 2.92 A) residues, respectively. ARG 188D forms a conventional carbon-hydrogen bond between the carboxyl group and the O7 atom of ligand. Whereas HIS 41D ( $\pi$ - $\pi$ stacked), CYS 44D, CYS 145D ( $\pi$-alkyl), and MET 165D (alkyl) involved in strengthening hydrophobic junction.

The isoquercitrin and rutin showed binding affinity of $-7.9 \mathrm{kcal} / \mathrm{mol}$ and $-7.6 \mathrm{kcal} / \mathrm{mol}$, respectively. Isoquercitrin forms polar interactions with HIS 41D, LEU 141D, GLY 143D, GLU 166D, GLN 192D, and hydrophobic contacts with THR 25D, HIS 41D, VAL 42D, CYS 44D, MET 49D, PHE 140D, LEU 141D, ASN 142D, GLY 143D, SER 144D, CYS 145D, HIS 163D, MET 165D, GLU 166D, ARG 188D, GLN 189D, GLN 192D amino acids. Further enhancement in binding due to the formation of conventional carbon-hydrogen bonding of $\mathrm{O} 2$ atoms (chromene ring), C1, C4, C5, C6 (3, 4-dihydroxyphenyl ring), and MET 165D residue. Compound Isoquercitrin forms $\pi-\pi$ T-shape interactions with HIS $163 \mathrm{D}$, pi-alkyl interactions with CYS 145D residues.

Rutin forms multiple contact points, including various $\mathrm{H}$-bonded and nonbonded contacts within a radius of $4 \mathrm{~A}$ with the main protease of SARS-CoV-2. Hydrogen bond formation involves THR 26D, HIS 41D, PHE 140D, GLY 143D, GLU 166D amino acid residues. Further hydrophobic contacts with SER 1B, THR 25D, THR 26D, LEU 27D, HIS 41D, CYS 44D, THR 45D, MET 49D, PHE 140D, LEU 141D, ASN 142D, GLY 143D, SER 144D, CYS 145D, HIS 164D, MET 165D, GLU 166D amino acids give the complex its stability.

\subsection{Molecular docking of selected phytoconstituents with RdRp (7BW4).}

All phytochemicals were also docked against RdRp (7BW4) of SARS-CoV-2, and it was observed that the compounds exhibited substantial binding affinity with relatively important interactions. The docking score of all selected phytoconstituents was compared with standard drug remdesivir. As compared to the standard three compounds (table 2, Figure 3), euphrobianin, myrecetin and rutin had a higher binding affinity. 
Table 1. Binding interactions of ligands with the binding site of the main protease of SARS-CoV-2 (PDB ID:

\begin{tabular}{|c|c|c|}
\hline $\begin{array}{c}\text { Ligand with } \\
\text { docking score } \\
\text { (kcal/mol) }\end{array}$ & H-bonding & Non-bonding \\
\hline $\begin{array}{l}\text { Euphrobianin } \\
(-8.4)\end{array}$ & $\begin{array}{l}\text { LEU 141D, ASN 142D, } \\
\text { GLY143D, } \\
\text { GLU166D, ARG188D }\end{array}$ & $\begin{array}{l}\text { HIS 41D, TYR 54D, LEU141D, ASN 142D, GLY 143D, SER } \\
\text { 144D, CYS 145D, HIS 164D, MET 165D, GLU166D, PRO168D, } \\
\text { ASP 187D, ARG188D, GLN 189D }\end{array}$ \\
\hline $\begin{array}{l}\text { Quercetin,3-o- } \\
\text { alpha- } \\
\text { rhamnoside } \\
(-8.1)\end{array}$ & $\begin{array}{l}\text { THR 26D, GLY 143D, GLU } \\
\text { 166D }\end{array}$ & $\begin{array}{l}\text { THR 25D, THR 26D, HIS 41D, MET 49D, TYR 54D, ASN 142D, } \\
\text { GLY 143D, CYS 145D, HIS 164D, MET 165D, GLU 166D, ASP } \\
\text { 187D, ARG 188D }\end{array}$ \\
\hline $\begin{array}{l}\text { Isoquercitrin } \\
(-7.9)\end{array}$ & $\begin{array}{l}\text { HIS 41D, LEU 141D, GLY } \\
\text { 143D, GLU 166D, GLN 192D }\end{array}$ & $\begin{array}{l}\text { THR 25D, HIS 41D, VAL 42D, CYS 44D, MET 49D, PHE 140D, } \\
\text { LEU 141D, ASN 142D, GLY 143D, SER 144D, CYS 145D, HIS } \\
\text { 163D, MET 165D, GLU 166D, ARG 188D, GLN 189D, GLN 192D }\end{array}$ \\
\hline $\begin{array}{l}\text { Rutin } \\
(-7.6)\end{array}$ & $\begin{array}{l}\text { THR 26D, HIS 41D, PHE } \\
\text { 140D, GLY 143D, GLU 166D }\end{array}$ & $\begin{array}{l}\text { SER 1B, THR 25D, THR 26D, LEU 27D, HIS 41D, CYS 44D, THR } \\
\text { 45D, MET 49D, PHE 140D, LEU 141D, ASN 142D, GLY 143D, } \\
\text { SER 144D, CYS 145D, HIS 164D, MET 165D, GLU 166D }\end{array}$ \\
\hline $\begin{array}{l}\text { Lopinavir } \\
(-7.3)\end{array}$ & GLY 143D & $\begin{array}{l}\text { THR 25D, THR 26D, PHE 140D, LEU 141D, LEU 27D, SER 143D, } \\
\text { CYS 145D, HIS 163D, HIE 164D, MET 265D, LEU 167D, PRO } \\
\text { 168D, GLN 192D, ALA 191D, THR 190D, MET 49D, SER 46D, } \\
\text { THR 45D, CYS 44D, VAL 42D, HIE 41D }\end{array}$ \\
\hline
\end{tabular}

A
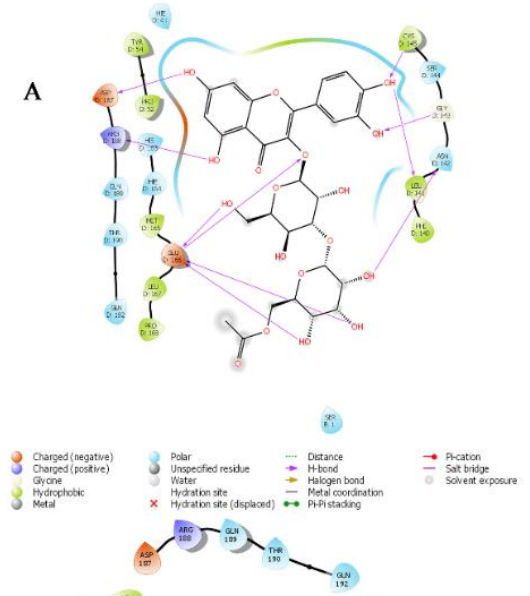

$\mathrm{C}$
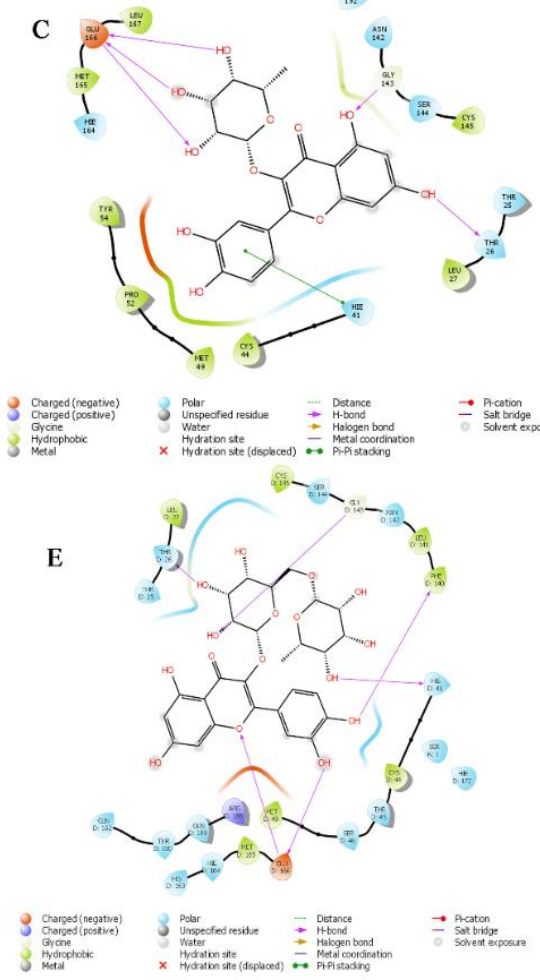

B

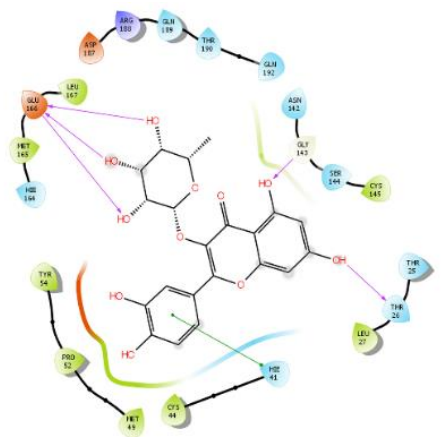

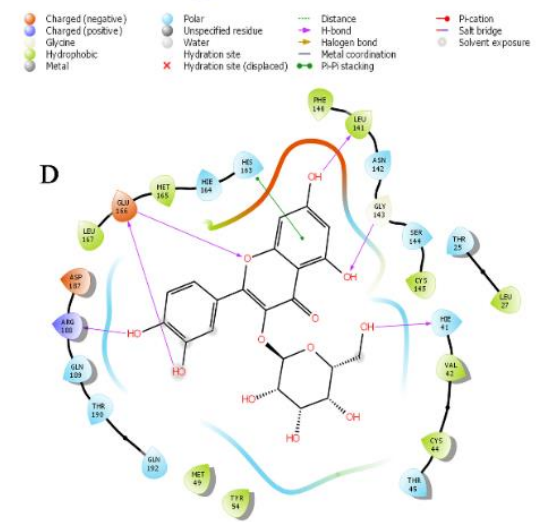

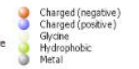
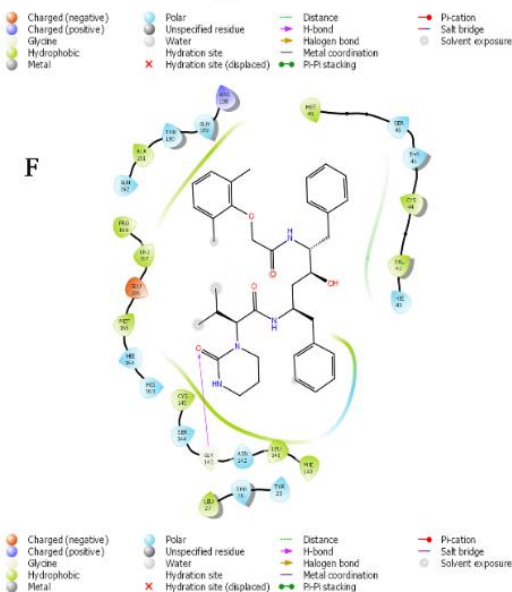

Figure 2. The binding interaction of (A) Euphrobianin; (B) Quercetin,3-O-Alpha-Rhamnoside; (C) Quercetin-3O-Rhamnopyranoside; (D) Isoquercitrin; (E) Rutin; (F) Lopinavir with the binding site of SARS-CoV-2 main protease (Mro) (PDB ID: 6m2n). 
Out of the all compounds, the Euphrobianin showed the highest binding energy value of $-6.1 \mathrm{kcal} / \mathrm{mol}$ founding polar hydrogen-bonding interactions with ASP 477A, ARG 640A, THR 643A, ARG 651A, hydrophobic with ASP 303A, ARG 305A, ASP 477A, ARG 640A, HIS 642A, THR 643A, CYS 646A, SER 647A, LEU 648A, ARG 651A, VAL 737A amino acids.

Hydrophobic interactions include characteristics of charged interaction with ASP 304A ( $\pi$-anion) and ARG 640A ( $\pi$-cation). CYS 646A and SET 647A amino acid residues from conventional hydrogen bonding with $\mathrm{C} 3, \mathrm{C} 5$, and $\mathrm{C} 7$ atoms of euphorbianin.

Myricetin and rutin have binding energy -5.7 and $-5.5 \mathrm{kcal} / \mathrm{mol}$, respectively. Both phytocompounds, myricetin and rutin, commonly form hydrogen bonding with ASP 477A and ARG 651A, hydrophobic interactions with ASP 477A, ASP 481A, LYS 641A, THR 643A, ARG 651A, charged contacts ASP 304A ( $\pi$-anion), ARG 640A ( $\pi$-cation) amino acids. Rutin also shows polar contacts with ASP 303A, ASP 304A, ASP 481A, CYS 646A, and hydrophobic with SER 647 A, LEU 648A in contrast to compound 11 showing polar LYS 641A, hydrophobic GLU 474A, HIS 642A, THR 643A, ARG 651A, VAL 737A amino acids.

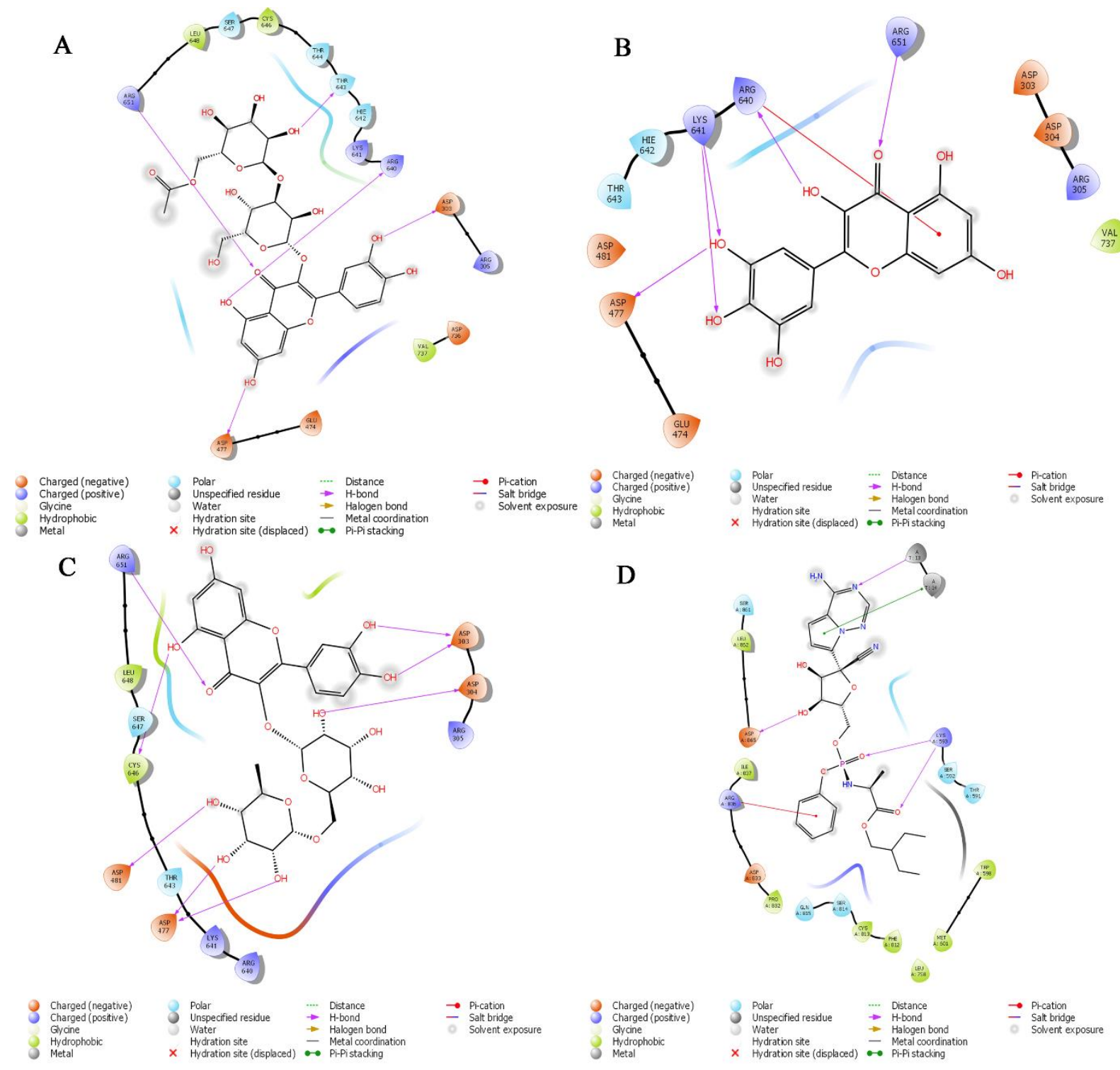

Figure 3. The binding interaction of (A) Euphrobianin; (B) Myricetin; (C) Rutin; (D) Remdesivir with the binding site of RdRp of SARS-CoV-2 (PDB ID: 7BW4). 
Table 2. Binding interactions of ligands with the binding site of RdRp of SARS-CoV-2 (PDB ID: 7BW4)

\begin{tabular}{l|l|l}
$\begin{array}{l}\text { Ligand } \begin{array}{r}\text { with } \\
\text { docking } \\
\text { score }\end{array} \\
\text { Kcal/mol) }\end{array}$ & H-bonding & Non-bonding \\
\hline $\begin{array}{l}\text { Euphrobianin } \\
(-6.1)\end{array}$ & $\begin{array}{l}\text { ASP 477A, ARG 640A, THR 643A, } \\
\text { ARG 651A }\end{array}$ & $\begin{array}{l}\text { ASP 303A, ARG 305A, ASP 477A, ARG 640A, HIS 642A, } \\
\text { THR 643A, CYS 646A, SER 647A, LEU 648A, ARG } \\
\text { 651A, VAL 737A }\end{array}$ \\
\hline $\begin{array}{l}\text { Myricetin } \\
(-5.7)\end{array}$ & ASP 477A, LYS 641A, ARG 651A & $\begin{array}{l}\text { ASP 304A, GLU 474A, ASP 477A, ASP 481A, ARG 640A, } \\
\text { LYS 641A, HIS 642A, THR 643A, ARG 651A, VAL 737A }\end{array}$ \\
\hline $\begin{array}{l}\text { Rutin } \\
(-5.5)\end{array}$ & ASP 303A, ASP 304A, ASP 477A, & $\begin{array}{l}\text { ASP 303A, ASP 304A, ASP 477A, ASP 481A, ARG 640A, } \\
\text { LYS 641A, THR 643A, CYS 646A, SER 647 A, LEU 648A, } \\
\text { ARG 651A }\end{array}$ \\
\hline $\begin{array}{l}\text { Remdesivir } \\
(-5.2)\end{array}$ & ASP 481A, CYS 646A, ARG 651A 593A, ARG 836A, ASP 865A & $\begin{array}{l}\text { SER 593A, THR 591A, TRP 598A, MET 601A, PHE 812A, } \\
\text { CYS 813A, SER 814A, GLN 815A, PRO 832A, ASP 833A, }\end{array}$ \\
& \multicolumn{1}{|l}{ ILE 837A, SER 861A, LEU 862A }
\end{tabular}

\subsection{Screening of drug-likeness and in silico toxicity studies.}

Druglikeness evaluation of all selected phytoconstituents was performed using the Schrodinger QuikProp module. Out of 26 selected phytoconstituents, 13 had passed the Lipinski rule of five. Other compounds had up to two violations which are acceptable for natural products (Table 3). Toxicological evaluation of selected phytoconstituents was performed by the QSAR modeling method using VEGA-QSAR (Table 4). The results represented as applicability domain index (ADI) scores calculated by algorithm incorporated in VEG-QSAR software. Positive results of ADI > 0.5 are considered as indicators of reliability effect. All phytoconstituents found to be non-mutagenic (SarPy/IRFMN, ISS and KNN/ReadAcross, assessment and prediction) except myricetin that may have mutagenicity according to KNN/Read-Across model [30]. Also, all chemical constituents do not have carcinogenicity (CAESAR model, assessment, and prediction) [31]. Phytocompounds euphorbianin and rutin do not show developmental toxicity (PG model assessment and prediction) [32], and all selected compounds are found to be inactive for Thyroid hormone receptor $\alpha / \beta$ (NRMEA, assessment, and prediction). There is very low reliability for myricetin to have skin sensitivity. Conversely, other chemical constituents do not have skin sensitivity (CAESAR model, assessment, and prediction) [33]. However, with low reliability of the IRFMN (assessment and prediction) model suggests that all constituents should be considered for their hepatotoxic potentials. Thus, overall euphorbianin and rutin can be suitable for further in vitro and in vivo assessment for its inhibitory potential against SARS-CoV-2.

Table 3. Drug-likeness profile of selected phytoconstituents.

\begin{tabular}{l|l|l|l|l|l|l|l|l}
$\begin{array}{l}\text { Sr. } \\
\text { no }\end{array}$ & Name of Compound & $\begin{array}{l}\text { MW } \\
(\mathbf{g} / \mathbf{m o l})\end{array}$ & $\begin{array}{l}\text { No. of } \\
\text { rotatable } \\
\text { bond }\end{array}$ & $\begin{array}{l}\text { H- } \\
\text { accepter }\end{array}$ & $\begin{array}{l}\text { H- } \\
\text { Donor }\end{array}$ & LogP & LogS & $\begin{array}{l}\text { GI } \\
\text { permeability }\end{array}$ \\
\hline 1 & Aesculetin & 178.14 & 0 & 4 & 2 & 1.25 & -2.28 & High \\
\hline 2 & Coumarin,6-7-8-Trimethoxy & 236.22 & 3 & 5 & 0 & 2.46 & -2.69 & High \\
\hline 3 & Daphnoretin & 352.29 & 3 & 7 & 1 & 2.87 & -4.44 & High \\
\hline 4 & Ellagic Acid & 302.19 & 0 & 8 & 4 & 0.79 & -2.94 & High \\
\hline 5 & Scopoletin & 192.17 & 1 & 4 & 1 & 1.86 & -2.46 & High \\
\hline 6 & Isoscopoletin & 192.17 & 1 & 4 & 1 & 1.86 & -2.46 & High \\
\hline 7 & Umbelliferone & 162.14 & 0 & 3 & 1 & 1.44 & -2.46 & High \\
\hline 8 & Afzelin & 432.38 & 3 & 10 & 6 & 1.84 & -3.47 & Low \\
\hline 9 & Euphrobianin & 668.55 & 9 & 18 & 10 & 2.22 & -2.88 & Low \\
\hline 10 & Kaempferol & 286.24 & 1 & 6 & 4 & 1.70 & -3.31 & High \\
\hline 11 & Myricetin & 318.24 & 1 & 8 & 6 & 1.08 & -3.01 & Low \\
\hline 12 & Myricitrin & 464.38 & 3 & 12 & 8 & 0.92 & -3.20 & Low
\end{tabular}




\begin{tabular}{|c|c|c|c|c|c|c|c|c|}
\hline $\begin{array}{l}\text { Sr. } \\
\text { no }\end{array}$ & Name of Compound & $\begin{array}{l}\text { MW } \\
(\mathrm{g} / \mathrm{mol})\end{array}$ & $\begin{array}{l}\text { No. of } \\
\text { rotatable } \\
\text { bond }\end{array}$ & $\begin{array}{l}\text { H- } \\
\text { accepter }\end{array}$ & $\begin{array}{l}\text { H- } \\
\text { Donor }\end{array}$ & $\log P$ & $\log S$ & $\begin{array}{l}\text { GI } \\
\text { permeability }\end{array}$ \\
\hline 13 & Quercetin & 302.24 & 1 & 7 & 5 & 1.63 & -3.16 & High \\
\hline 14 & $\begin{array}{l}\text { Quercetin,3-O-Alpha- } \\
\text { Rhamnoside }\end{array}$ & 448.38 & 3 & 11 & 7 & 0.49 & -3.20 & Low \\
\hline 15 & $\begin{array}{l}\text { Quercetin-3-O- } \\
\text { Rhamnopyranoside }\end{array}$ & 448.38 & 3 & 11 & 7 & 0.49 & -3.20 & Low \\
\hline 16 & Quercetrin & 448.38 & 3 & 11 & 7 & 0.49 & -3.20 & Low \\
\hline 17 & Quercimeritrin & 464.379 & 4 & 12 & 8 & -0.54 & -2.92 & High \\
\hline 18 & Quercitrin & 432.381 & 3 & 10 & 6 & 1.52 & -3.41 & Low \\
\hline 19 & Iso Quercitrin & 464.379 & 4 & 12 & 8 & -0.54 & -3.00 & High \\
\hline 20 & Iso Rhamnetin & 316.265 & 2 & 7 & 4 & 2.29 & -3.11 & High \\
\hline 21 & Rutin & 610.521 & 6 & 16 & 10 & -1.69 & -2.91 & Low \\
\hline 22 & Xanthorhamnin & 770.69 & 9 & 20 & 11 & -2.53 & -2.90 & Low \\
\hline 23 & Ingenol Triacetate & 474.55 & 4 & 8 & 1 & 2.53 & -5.01 & High \\
\hline 24 & Jolkinolide A & 314.425 & 0 & 3 & 0 & 4.14 & -4.96 & High \\
\hline 25 & Ent Kaur-16-Ene-3-Beta-Ol: & 288.475 & 1 & 1 & 1 & 4.95 & -4.50 & High \\
\hline 26 & $\begin{array}{l}\text { Kaurane,16-Alpha, } \\
\text { Trihydroxy:Ent }\end{array}$ & 336.472 & 2 & 3 & 3 & 3.21 & -3.47 & High \\
\hline
\end{tabular}

Table 4. Toxicity Assessment selected active phytoconstituents (QSAR Models).

\begin{tabular}{|c|c|c|c|c|c|}
\hline Toxicity Test & Euphrobianin & Myricetin & $\begin{array}{l}\text { Quercetin,3- } \\
\text { O-Alpha- } \\
\text { Rhamnoside }\end{array}$ & Iso quercitrin & Rutin \\
\hline $\begin{array}{l}\text { Mutagenicity (Ames test) model } \\
(\text { SarPy/IRFMN) - assessment }\end{array}$ & $0.925 * * *$ & $0.567 *$ & $0.744 * *$ & $0.695 * *$ & $0.932 * * *$ \\
\hline $\begin{array}{lll}\text { Mutagenicity } & \text { (Ames test) } & \text { model } \\
(\text { SarPy/IRFMN) } & \text { prediction }\end{array}$ & $\begin{array}{l}\text { NON- } \\
\text { Mutagenic }\end{array}$ & $\begin{array}{l}\text { NON- } \\
\text { Mutagenic }\end{array}$ & $\begin{array}{l}\text { NON- } \\
\text { Mutagenic }\end{array}$ & $\begin{array}{l}\text { NON- } \\
\text { Mutagenic }\end{array}$ & $\begin{array}{l}\text { NON- } \\
\text { Mutagenic }\end{array}$ \\
\hline $\begin{array}{lcc}\text { Mutagenicity } \quad \text { (Ames } & \text { test) } & \text { model } \\
(\text { KNN/Read-Across) }- \text { assessment } & \end{array}$ & $0.80 * *$ & $0.847 * *$ & $0.717 * *$ & $0.717 * *$ & $0.807 * *$ \\
\hline $\begin{array}{l}\text { Mutagenicity (Ames test) } \text { model } \\
\text { (KNN/Read-Across) - prediction }\end{array}$ & $\begin{array}{l}\text { NON- } \\
\text { Mutagenic }\end{array}$ & Mutagenic & $\begin{array}{l}\text { NON- } \\
\text { Mutagenic }\end{array}$ & $\begin{array}{l}\text { NON- } \\
\text { Mutagenic }\end{array}$ & $\begin{array}{l}\text { NON- } \\
\text { Mutagenic }\end{array}$ \\
\hline $\begin{array}{lll}\text { Carcinogenicity } & \text { model } & \text { (CAESAR) } \\
\text { assessment } & & \end{array}$ & $0.729 * *$ & $0.793 * *$ & $0.636^{* *}$ & $0.631 * *$ & $0.721 * *$ \\
\hline $\begin{array}{llll}\begin{array}{l}\text { Carcinogenicity } \\
\text { prediction }\end{array} & \text { model } & \text { (CAESAR) } & \\
\end{array}$ & $\begin{array}{l}\text { NON- } \\
\text { Carcinogen }\end{array}$ & $\begin{array}{l}\text { NON- } \\
\text { Carcinogen }\end{array}$ & $\begin{array}{l}\text { NON- } \\
\text { Carcinogen }\end{array}$ & $\begin{array}{l}\text { NON- } \\
\text { Carcinogen }\end{array}$ & $\begin{array}{l}\text { NON- } \\
\text { Carcinogen }\end{array}$ \\
\hline $\begin{array}{ll}\text { Developmental/Reproductive } & \text { Toxicity } \\
\text { library }(\mathrm{PG}) \text { - assessment } & \end{array}$ & $\begin{array}{l}\text { Outside } \\
\text { domain }\end{array}$ & $0.874 * *$ & $0.877 * *$ & $0.874 * *$ & $\begin{array}{l}\text { Outside } \\
\text { domain }\end{array}$ \\
\hline $\begin{array}{l}\text { Developmental/Reproductive } \\
\text { library }(\mathrm{PG}) \text { - prediction }\end{array}$ & NON-Toxicant & Toxicant & Toxicant & Toxicant & NON-Toxicant \\
\hline $\begin{array}{l}\text { Thyroid Receptor Alpha and Beta effect } \\
\text { (NRMEA) - assessment }\end{array}$ & $0.962 * * *$ & $0.932 * * *$ & $0.923 * * *$ & $0.93^{* * *}$ & $1 * * *$ \\
\hline $\begin{array}{l}\text { Thyroid Receptor Alpha and Beta effect } \\
\text { (NRMEA) - prediction }\end{array}$ & Inactive & Inactive & & & Inactive \\
\hline $\begin{array}{l}\text { Skin Sensitization model (CAESAR) - } \\
\text { assessment }\end{array}$ & $\begin{array}{l}\text { Outside } \\
\text { domain }\end{array}$ & $0.431^{*}$ & $\begin{array}{l}\text { Outside } \\
\text { domain }\end{array}$ & $0.359 *$ & $\begin{array}{l}\text { Outside } \\
\text { domain }\end{array}$ \\
\hline $\begin{array}{l}\text { Skin Sensitization model (CAESAR) - } \\
\text { prediction }\end{array}$ & $\begin{array}{l}\text { NON- } \\
\text { Sensitizer }\end{array}$ & Sensitizer & $\begin{array}{l}\text { NON- } \\
\text { Sensitizer }\end{array}$ & $\begin{array}{l}\text { NON- } \\
\text { Sensitizer }\end{array}$ & $\begin{array}{l}\text { NON- } \\
\text { Sensitizer }\end{array}$ \\
\hline Hepatotoxicity model (IRFMN) - assessment & $0.549^{*}$ & $0.775 * *$ & $0.54 *$ & $0.537 *$ & $0.556^{*}$ \\
\hline Hepatotoxicity model (IRFMN) - prediction & Toxic & Toxic & Toxic & Toxic & Toxic \\
\hline
\end{tabular}

\section{Conclusions}

We performed a detailed in silico study of twenty-six phytoconstituents obtained from the plant E. hirta to find potential candidates against SARS-CoV-2. All the phytoconstituents belong to either category of flavonoid or coumarins. The molecular docking studies were performed using two different targets, namely $\mathrm{M}^{\text {pro }}$ and RdRp. Based on the molecular docking 
study compared with the standard drug, we screened four compounds, namely euphrobianin, quercetin 3-o-alpha-rhamnoside, isoquercitrin, and rutin, against the target $\mathrm{M}^{\text {pro }}$ while three phytoconstituents euphorbianin, myricetin and rutin were screened against the target RdRp. Euphorbianin and rutin were found common against both targets. All the screened phytoconstituents based on docking score were evaluated for in silico toxicity profiles, and except myrectin all were predicted safe. Results of euphorbianin and rutin were found more interesting as both compounds had high binding affinity against both targets. Finally, we want to conclude that euphrobianin, quercetin,3-o-alpha-rhamnoside, isoquercitrin, and rutin could be rapidly further explored as they may have the potential to fight against COVID-19.

\section{Funding}

Non-funded.

\section{Acknowledgments}

We are thankful to Sumandeep Vidyapeeth Deemed to be University for supporting us to conduction this research wok.

\section{Conflicts of Interest}

There are no conflicts of interest.

\section{References}

1. Sohrabi, C.; Alsafi, Z.; O'Neill, N.; Khan, M.; Kerwan, A.; Al-Jabir, A.; Iosifidis, C.; Agha, R. World Health Organization declares global emergency: A review of the 2019 novel coronavirus (COVID-19). International Journal of Surgery 2020, 76, 71-76, https://doi.org/10.1016/j.ijsu.2020.02.034.

2. Wu, D.; Wu, T.; Liu, Q.; Yang, Z. The SARS-CoV-2 outbreak: What we know. International Journal of Infectious Diseases 2020, 94, 44-48, https://doi.org/10.1016/j.ijid.2020.03.004.

3. In Coronavirus disease (COVID-19) Situation Report - 175 , https://www.who.int/emergencies/diseases/novel-coronavirus-2019/situation-reports.

4. Guo, G.; Ye, L.; Pan, K.; Chen, Y.; Xing, D.; Yan, K.; Chen, Z.; Ding, N.; Li, W.; Huang, H.; Zhang, L.; Li, X.; Xue, X. New Insights of Emerging SARS-CoV-2: Epidemiology, Etiology, Clinical Features, Clinical Treatment, and Prevention. Frontiers in Cell and Developmental Biology 2020, 8, 1-22, https://doi.org/10.3389/fcell.2020.00410.

5. Tu, Y. F.; Chien, C. S.; Yarmishyn, A. A.; Lin, Y. Y.; Luo, Y. H.; Lin, Y. T.; Lai, W. Y.; Yang, D. M.; Chou, S. J.; Yang, Y. P.; Wang, M. L.; Chiou, S. H. A review of sars-cov-2 and the on going clinical trials. International Journal of Molecular Sciences 2020, 21, https://doi.org/10.3390/ijms21072657.

6. Wang, L.; Wang, Y.; Ye, D.; Liu, Q. Review of the 2019 novel coronavirus (SARS-CoV-2) based on current evidence. International Journal of Antimicrobial Agents 2020, 55, 105948, https://doi.org/10.1016/j.ijantimicag.2020.105948.

7. Mirzaie, A.; Halaji, M.; Dehkordi, F. S.; Ranjbar, R.; Noorbazargan, H. A narrative literature review on traditional medicine options for treatment of corona virus disease 2019 (COVID-19). Complementary Therapies in Clinical Practice 2020, 40, 101214, https://doi.org/10.1016/j.ctcp.2020.101214.

8. Sanders, J. M.; Monogue, M. L.; Jodlowski, T. Z.; Cutrell, J. B. Pharmacologic Treatments for Coronavirus Disease 2019 (COVID-19): A Review. JAMA - Journal of the American Medical Association 2020, 323, 1824-1836, https://doi.org/10.1001/jama.2020.6019.

9. Wu, R.; Wang, L.; Kuo, H. C. D.; Shannar, A.; Peter, R.; Chou, P. J.; Li, S.; Hudlikar, R.; Liu, X.; Liu, Z.; Poiani, G. J.; Amorosa, L.; Brunetti, L.; Kong, A. N. An Update on Current Therapeutic Drugs Treating COVID-19. Current Pharmacology Reports 2020, 6, 56-70, https://doi.org/10.1007/s40495-020-00216-7.

10. Parmar, G.; Pundarikakshudu, K.; Balaraman, R.; Sailor, G. Amelioration of anaphylaxis, mast cell degranulation and bronchospasm by Euphorbia hirta L. extracts in experimental animals. Beni-Suef 
University Journal of Basic and Applied Sciences 2018, 7, 127-134, https://doi.org/10.1016/j.bjbas.2017.11.001.

11. Mwine, J. T.; van Damme, P. Why do euphorbiaceae tick as medicinal plants? a review of euphorbiaceae family and its medicinal features. Journal of Medicinal Plants Research 2011, 5, 652-662, https://www.researchgate.net/publication/228478254_Why_do_Euphorbiaceae_tick_as_medicinal_Plants_ A_review_of_Euphorbiaceae_family_and_its_medicinal_features.

12. Kemper, K. J.; Lester, M. R. Alternative asthma therapies: An evidence-based review. Contemporary Pediatrics 1999, 16, 162-195, https://www.researchgate.net/profile/Kathi-Kemper2/publication/264957106_Alternative_asthma_therapies_An_evidence-

based_review/links/55242daa0cf2caf11bfcc253/Alternative-asthma-therapies-An-evidence-basedreview.pdf.

13. Aquil, M. Euphorbianin, a new glycoside from Euphorbia hirta Linn. Global Journal of Pure and applied science 1999, 5, 371.

14. Yusuf, M.; Wahab, M. A.; Yousuf, M. D.; Chowdhury, J. U.; Begum, J., Some tribal medicinal plants of Chittagong hill tracts, Bangladesh. Bangladesh Journal of Plant Taxonomy 2007, 14 (2), 117-128..

15. Parmar, G. R.; Pundarikakshudu, K., Comparative pharmacognostic and phytochemical standardization of Euphorbia hirta L. and Euphorbia thymifolia L. American Journal of Pharmtech Research 2017, 7, 351-544.

16. Anjaria, J.; Parabia, M.; Bhatt, G.; Khamar, R., A glossary of selected indigenous medicinal plants of India. 1997,

https://www.researchgate.net/publication/324978847_Comparative_Pharmacognostic_and_Phytochemical_ Standardization_of_Euphorbia_hirta_L_and_Euphorbia_thymifolia_L.

17. Capasso, F.; Gaginella, T.S.; Grandolini, G.; Izzo, A.A. Phytotherapy: a Quick Reference to Herbal Medicine. Springer-Verlag Berlin Heidelberg: Berlin, Germany 2010, 9, 164, http://www.ethnopharmacologia.org/bibliotheque-ethnopharmacologie/phytotherapy-a-quick-reference-toherbal-medicine.

18. Shah, A. P.; Parmar, G. R.; Sailor, G. U.; Seth, A. K. Antimalarial Phytochemicals Identification from Euphorbia Hirta against Plasmepsin Protease: an In Silico Approach. Folia medica 2019, 61, 584-593, https://doi.org/10.3897/folmed.61.e47965.

19. Karak, P. J. I. J. o. P. S. Research, Biological activities of flavonoids: an overview. Int J Pharm Sci \& Res 2019, 10 (4), 1567-1574, https://doi.org/10.13040/IJPSR.0975-8232.10(4).1567-74.

20. Jo, S.; Kim, S.; Shin, D. H.; Kim, M.-S. Inhibition of SARS-CoV 3CL protease by flavonoids. Journal of enzyme inhibition and medicinal chemistry 2020, 35, 145-151, https://doi.org/10.1080/14756366.2019.1690480.

21. Das, A.; Pandita, D.; Jain, G. K.; Agarwal, P.; Grewal, A. S.; Khar, R. K.; Lather, V. Role of phytoconstituents in the management of COVID-19. Chem Biol Interact 2021, 341, 109449-109449, https://doi.org/10.1016/j.cbi.2021.109449.

22. Khodadadi, E.; Maroufi, P.; Khodadadi, E.; Esposito, I.; Ganbarov, K.; Espsoito, S.; Yousefi, M.; Zeinalzadeh, E.; Kafil, H. S. Study of combining virtual screening and antiviral treatments of the Sars-CoV2 (Covid-19). Microbial Pathogenesis 2020, 146, 104241-104241, https://doi.org/10.1016/j.micpath.2020.104241.

23. Kirchdoerfer, R. N.; Ward, A. B. Structure of the SARS-CoV nsp12 polymerase bound to nsp7 and nsp8 cofactors. Nature Communications 2019, 10, 2342, https://doi.org/10.1038/s41467-019-10280-3.

24. Farnsworth, N. R. NAPRALERT database. Chicago, University of Illinois at Chicago, IL, March: 1995.

25. Figueroa, J. P.; Bottazzi, M. E.; Hotez, P.; Batista, C.; Ergonul, O.; Gilbert, S.; Gursel, M.; Hassanain, M.; Kim, J. H.; Lall, B.; Larson, H.; Naniche, D.; Sheahan, T.; Shoham, S.; Wilder-Smith, A.; Strub-Wourgaft, N.; Yadav, P.; Kang, G. Urgent needs of low-income and middle-income countries for COVID-19 vaccines and therapeutics. The Lancet 2021, 397, 562-564, https://doi.org/10.1016/S0140-6736(21)00242-7.

26. Shah, S.; Chaple, D.; Arora, S.; Yende, S.; Mehta, C.; Nayak, U. Prospecting for Cressa cretica to treat COVID-19 via in silico molecular docking models of the SARS-CoV-2. Journal of Biomolecular Structure and Dynamics 2021, 1-9, https://doi.org/10.1080/07391102.2021.1872419.

27. Huang, J.; Song, W.; Huang, H.; Sun, Q. Pharmacological Therapeutics Targeting RNA-Dependent RNA Polymerase, Proteinase and Spike Protein: From Mechanistic Studies to Clinical Trials for COVID-19. Journal of clinical medicine 2020, 9, 1131, https://doi.org/10.3390/jcm9041131. 
28. Yang, Y.; Islam, M. S.; Wang, J.; Li, Y.; Chen, X. Traditional Chinese Medicine in the Treatment of Patients Infected with 2019-New Coronavirus (SARS-CoV-2): A Review and Perspective. International journal of biological sciences 2020, 16, 1708-1717, https://doi.org/10.7150/ijbs.45538.

29. Gyuris, A.; Szlávik, L.; Minárovits, J.; Vasas, A.; Molnár, J.; Hohmann, J. Antiviral activities of extracts of Euphorbia hirta L. against HIV-1, HIV-2 and SIVmac251. In vivo (Athens, Greece) 2009, 23, 429-32, https://pubmed.ncbi.nlm.nih.gov/19454510/.

30. Votano, J. R.; Parham, M.; Hall, L. H.; Kier, L. B.; Oloff, S.; Tropsha, A.; Xie, Q.; Tong, W. Three new consensus QSAR models for the prediction of Ames genotoxicity. Mutagenesis 2004, 19, 365-377, https://doi.org/10.1093/mutage/geh043.

31. Fjodorova, N.; Vracko, M.; Novic, M.; Roncaglioni, A.; Benfenati, E. New public QSAR model for carcinogenicity. Chemistry Central journal 2010, 4 Suppl 1, S3-S3, https://doi.org/10.1186/1752-153X-4S1-S3.

32. Simms, L.; Rudd, K.; Palmer, J.; Czekala, L.; Yu, F.; Chapman, F.; Trelles Sticken, E.; Wieczorek, R.; Bode, L. M.; Stevenson, M.; Walele, T. The use of human induced pluripotent stem cells to screen for developmental toxicity potential indicates reduced potential for non-combusted products, when compared to cigarettes. Current Research in Toxicology 2020, 1, 161-173, https://doi.org/10.1016/j.crtox.2020.11.001.

33. Chaudhry, Q.; Piclin, N.; Cotterill, J.; Pintore, M.; Price, N. R.; Chrétien, J. R.; Roncaglioni, A. Global QSAR models of skin sensitisers for regulatory purposes. Chemistry Central journal 2010, 4 Suppl 1, S5S5, https://doi.org/10.1186/1752-153X-4-S1-S5. 